\title{
INVESTMENT IN INFORMATION AND COMMUNICATION TECHNOLOGY (ICT): A SOCIAL OVERHEAD CAPITAL FOR IMPROVING FINANCIAL SECTOR DEEPENING IN NIGERIA
}

\author{
*Olubukola AKINWUNMI, Prof. Abdurrahman ISIK \\ Nile University Nigeria, FCT, Abuja \\ *Corresponding Author
}

DOI: 10.46609/IJSSER.2020.v05i06.007 URL: https://doi.org/10.46609/IJSSER.2020.v05i06.007

\begin{abstract}
This paper explores the importance of ICT infrastructure for the deepening of financial services sector. It identified the components of ICT Investment that support the proliferation of access to financial services and reviewed data on ICT penetration indicators against financial depth indicators to suggest relationship between ICT investment and financial depth. The case of Nigeria was further examined towards proving the essentiality of ICT Investment and digital inclusion to promote access to financial services. We identified the challenges to digital inclusion from the perspective of investment in ICT and concluded that the constraints to financial inclusion in Nigeria is steeped in its inability of taking advantage of financial services accessible through the internet by the digital excluded populace. We therefore proposed some policy recommendation to improve on ICT investment and financial depth in Nigeria.
\end{abstract}

Keywords: Financial Deepening, ICT, Fintech, Financial Inclusion, Investment

JEL Classification: G2-Financial Economics $\backslash$ Financial Institutions and Services

\subsection{INTRODUCTION}

The prerequisite of resource mobilization for economic development continues to challenge most African countries. The development of the financial sectors of economies is pivotal to delivering requisite resource mobilization and bridging the financial intermediation deficit in most SubSaharan African countries and Nigeria in particular. Based on our computation using the data available on the world bank database (https://data.worldbank.org/), a review of Domestic Credit to Private sector by banks (as a percentage to GDP) in Nigeria for the period 2012 to 2018 indicated an average of 13. 40 per cent compared with 27.99 per cent for Sub-Saharan Africa, 


\section{International Journal of Social Science and Economic Research}

ISSN: $2455-8834$

Volume: 05, Issue: 06 "June 2020"

31.35 per cent for Kenya and 67.01 per cent for South Africa. Similarly, the financial exclusion rate of 36.8 per cent (EFInA, 2018) demonstrates that the Nigeria financial services sector is barely ankle-deep. Considering that, the exclusion rate is the lowest in the last two decades suggests that policies and initiatives for the development of the financial sector in Nigeria have recorded benign achievement in twenty years and requires transformational strategies.

However, the development achieved in the early 2000s in the telecommunication sector of the country is considered the foundational infrastructure which spurred the achievement that had placed the payments and settlement systems into global reckoning and attracted venture capitalist and private equity investor firms into the budding enterprises in the financial technology (Fintech) segment of the financial services sector. Fintechs in Nigeria are reputed to have opened up financial services especially access to credit to more Nigerians, especially in the area of personal and consumer credits within the last five years, thereby setting the stage for increased demand which may elevate output.

\section{Investment in ICT}

ICT investment covers a wide range of expenditure at both public and private sector level that increases the stock and capabilities for the collection, processing, distribution and usage of information in the production of products and services. ICT infrastructure investment includes expenditure that improves telecommunication in the country such as fixed telephone lines, fixed broadband, mobile cellular services etc. Such investment is made in the first instance by the public sector. However, in more developed economies, the private sector took the lead in building such investment stock. In Nigeria, the public sector also had invested in the early stage, but government had to deregulate the sector with the auctioning of licences for the operation of the mobile telephony infrastructure in the early 2000s. In addition, the diffusion of the usage of investment in ICT requires private investment in technologies that leverage the infrastructure. Therefore, investment in computer hardware and software, networking equipment, data processing and storage facilities are also regarded as investment in ICT.

This paper is, therefore, a qualitative consideration of the issues underlying the prerequisite for ICT infrastructural investment towards the deepening of the financial sector. It will explore expositions on financial sector development with a view to underscore the history of technological impact in the deepening of the financial system. Furthermore, this work underscores the importance of ICT as a social overhead capital by reviewing the impact on economic growth and financial sector development. It is hoped that the paper will steer debates on the place of ICT infrastructure in financials sector and economic development, generally. 
International Journal of Social Science and Economic Research

ISSN: $2455-8834$

Volume: 05, Issue: 06 "June 2020"

Following the introduction in this section, the theoretical and empirical underpinnings that provide foundation for underscoring the importance of ICT as a social overhead capital is examined in section two. Section three highlights the Nigerian experience and global insights to underscore impact of ICT on financial ssector using available data from the World Bank and the Central Bank of Nigeria to drive the essentiality of ICT infrastructure to development of the financial services sector. In section four, policy issues were raised while conclusions are drawn with recommendations for policy makers in section five.

\subsection{THEORETICAL AND EMPIRICAL REVIEW}

\subsection{Financial Sector Depth}

It is argued that the development of the Financial Services Sector is crucial to economic growth and development. Financial development is required for effective mobilization of savings and intermediation required to facilitate enterprise. It also enhances information availability, risk management and resource allocation. In the process of developing the financial sector, financial deepening is essential and comes first. Financial deepening is the improvement in access to financial services for a broad spectrum of people across social, race, economic and natural classes. It may be regarded as the first step in developing the financial sector as it is core to the mobilization of savings as well as the intermediation function of financial systems. In certain respect, it is used interchangeably with financial sector development especially in the context of developing countries. Literature abound on the nexus between financial deepening and economic growth as well as the causality argument between financial deepening and economic growth. Disparate views depending on the measures of financial deepening, the country studied and models makes the interrogation always relevant (Karimo \& Ogbonna, 2017).

The Access through Innovation sub-group of the G20 Financial Inclusion Experts Group identified the importance of financial inclusion to include, savings mobilization, access to finance, social and economic inclusion, and competition in the provision of financial services (Access Through Innovation Sub-Group of the G20 Financial Inclusion Experts Group, 2010)

\subsection{Investment in Information and Communication Technology: A Social Overhead Capital for Financial Sector Development?}

Information and Communication Technology (ICT) encompasses all systems comprising hardware and software, telecommunication facilities and networks of systems that facilitate capturing of data, processing data and utilizing intelligible information for decision making to enhance the process of production of goods and services and for the improvement of quality of life. 


\section{International Journal of Social Science and Economic Research}

ISSN: $2455-8834$

Volume: 05, Issue: 06 "June 2020"

It may be considered as the necessary infrastructure required for the production of information and the transfer of such information from the point of production to the point of requirement, harnessing technology for the purpose of enterprise and the provision of goods and services (Laudon \& Laudon, 2001) (Agboola, 2001). The infrastructure that enables ICT may therefore be considered as a social overhead capital in the light of submissions within various studies and the fact that it has the attributes of social overhead capital.

Studies indicated that mobile phones are having similar effects that fixed lines had on developed countries in the 1970s and 1980s, indicating that mobile phones contribute to national output and even have greater impact in developing nations because of the higher network effect of mobile phones compared to fixed lines. Hence, confirming the line of thought that ICT infrastructure is a social overhead capital. (Garbard \& Silber, 1978), examined the contribution of communication technology to the integration of financial markets. Their study reviewed the contribution of the telegraph to the integration of markets in the USA (Philadelphia-New York-New Orleans) as well as the impact of the transatlantic cable on the New Yok and London bonds markets amongst other technology enabling innovation and harmonisation of markets. It was indicated that the usage of telecommunication infrastructure by the market streamlined information asymmetry and reduced the time difference in terms of information transmission among markets thereby improving order execution and price differentials.

\subsection{Financial Inclusion, Digital Financial Services and Fintechs: The Nexus between ICT Infrastructure to Financial Sector Development}

Financial inclusion means that all working age adults have effective access to credit, savings, payments and insurance from formal service providers. Effective access involves convenient and responsible service delivery, at a cost affordable to the customer and sustainable for the provider with the result that financially excluded customers use formal financial services rather than existing informal options (Consultative Group for Assisting the Poor). Sequel to the global financial crises, the G20 and multilateral institutions such as the World Bank and the International Monetary Fund refocused attention on the need to strengthen financial sector development in the developing world. Indeed, there were claims that access to financial services enhances development especially towards lifting the poor out of poverty. The World Bank defines financial inclusion to mean that "individuals and businesses have access to useful and affordable financial services that meet their needs -transactions, payments, savings, credits and insurance- delivered in a responsible and sustainable way" (World Bank, 2019).

The limitations of traditional financial institutions have come to fore in current debate on how to tackle the problem of financial exclusion. The brick and mortar banking solutions is not meeting the needs of certain segment of the society that are vulnerable, weak and poor. The quest 


\section{International Journal of Social Science and Economic Research}

ISSN: $2455-8834$

Volume: 05, Issue: 06 "June 2020"

viability and profitability of traditional branch banking methods have excluded people in terms of cost, distance, culture and education. Digital innovation for availing and accessing financial services is now considered an alternative. Digital financial services therefore can be defined as the provision of financial services through electronic means usually over the mobile telephony and internet infrastructure (Akinwunmi, 2018). (Alliance for Financial Inclusion, 2016) defined Digital Financial Services (DFS) as "the broad range of financial services accessed and delivered through digital channels, including, credits, savings, remittances and insurance"

The Alliance for Financial Inclusion defines Fintech as "the use of technology and innovative business models in the provision of financial services" (Alliance for Financial Inclusion, 2016). It is a concactenation of the words "financial" and "technologies". Online credit providers have become prominent in the provision of credit to households in Nigeria as they are in several other countries. (Jagtiani \& Lemieux, 2018) in their investigation to determine whether Fintechs extend credit to those unserved by banks, indicated that Fintech firms are leveraging the prevalence of social media technology to better profile customer and manage information asymmetry arising from paucity of credit scoring on the unserved segments in the United States of America. Innovation such as big data, social media, artificial intelligence rely on appropriate infrastructure in the ICT to spur new models of addressing credit to those who were hitherto excluded as they are used in providing soft information on them. The study obtained data on borrowers from alternative lenders with details on geographic location examined to create a heat map of locations served. The heat map revealed that alternative fintech lenders had more borrowers in counties with lesser presence of banks and that those borrowers were more leveraged than the normal FICO rated borrowers. The analysis also revealed that fintech lenders were becoming more prominent in areas where bank branches were declining.

We expect that ICT, through its support for financial deepening should exert positive influence on savings mobilization and financial inclusion. In reviewing literature on the assessment of mobile telephony on financial inclusion, (Duncombe \& Boateng, 2009) highlighted some insights from the Grameen VPO Programme in Bangladesh, that social calls were mostly linked to addressing financial issues such as remittances and transactions thereby underscoring the importance of telecommunication to accessing information on finance and consummating financial and commercial transactions. Another study in Egypt by Goodman and Walia indicated that the frequent transfer of airtime among users is suggestive of the tendency for people to adopt electronic money. Furthermore, it was found in South Africa that the poor were using the WIZZIT mobile money services. 


\subsection{ICT INVESTMENT AND FINANCIAL SECTOR DEPTH-GLOBAL INSIGHT}

A review of data underscores the position that ICT infrastructure is a prerequisite social overhead capital to achieve financial deepening. A review of countries based on data on fixed broadband subscription and mobile cellular subscription, which are indicative of requisite ICT infrastructure, indicates that it can be inferred that the countries with better ICT infrastructure spread perform better with the measures of financial depth such as domestic credit to the private sector (as a percentage of GDP). It is also important to note that in recent years credit information system has improved in most countries because of the increasing availability of ICT infrastructure and increasing data sets available through ICT.

Figure 1: Fixed Broadband Subscription Per 100 People

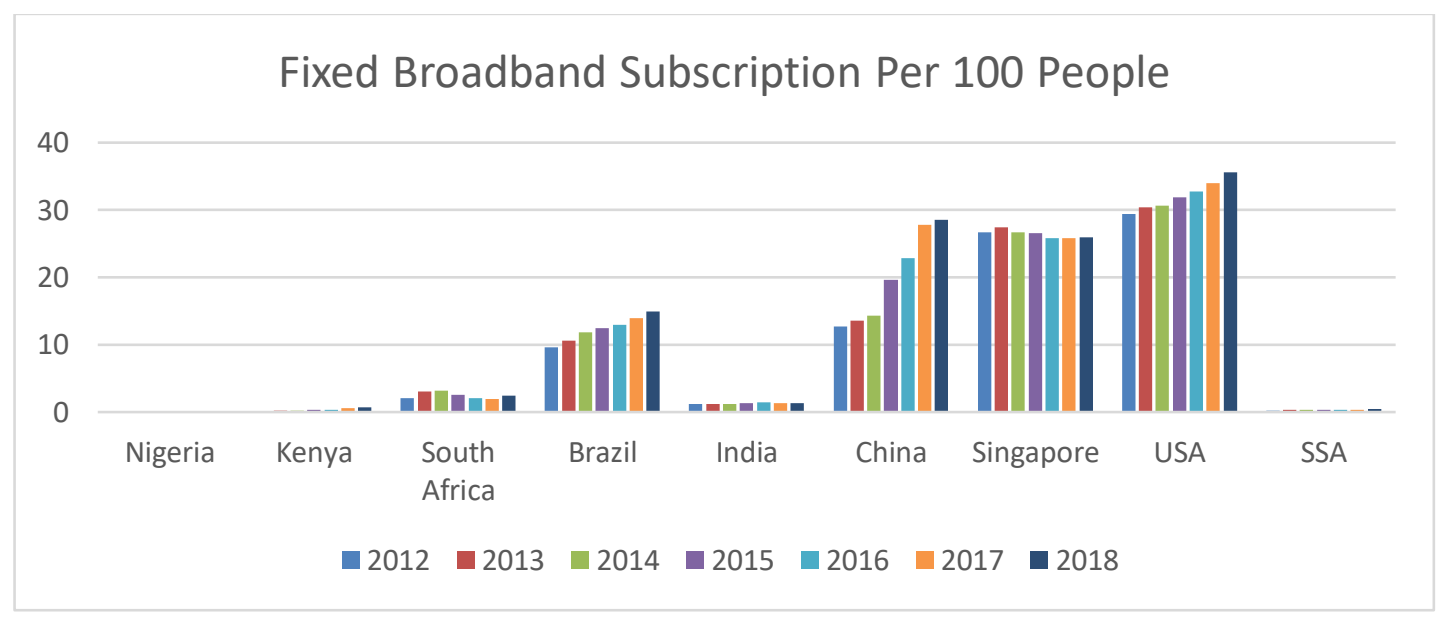

Data Sourced from https://data.worldbank.org/

USA, Singapore, China and Brazil have better financial depth and from the chart above it is obvious that they have better infrastructure for fixed broadband telecommunication than African countries especially Nigeria and other Sub-Saharan African countries which have less developed financial services sector. 
International Journal of Social Science and Economic Research

ISSN: 2455-8834

Volume: 05, Issue: 06 "June 2020"

Figure 2: Mobile Cellular Subscription Per 100 People

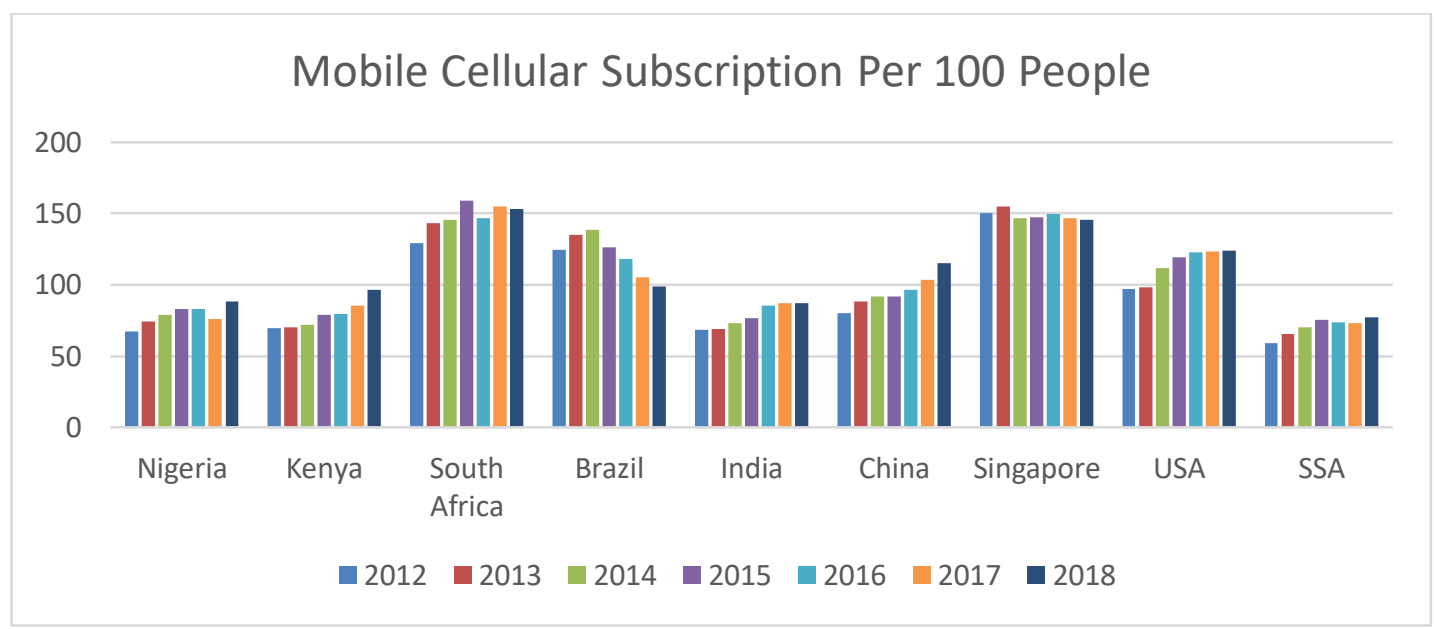

Data Sourced from https://data.worldbank.org/

Notwithstanding, the rapid growth in mobile phone penetration in Nigeria and other African countries, USA, Singapore, China and Brazil still maintain the edge ahead of Nigeria and their financial services sector is supported by the better access to mobile cellular telephony services as indicated in the chart above.

Figure 3: Domestic Credit to Private Sector by Banks

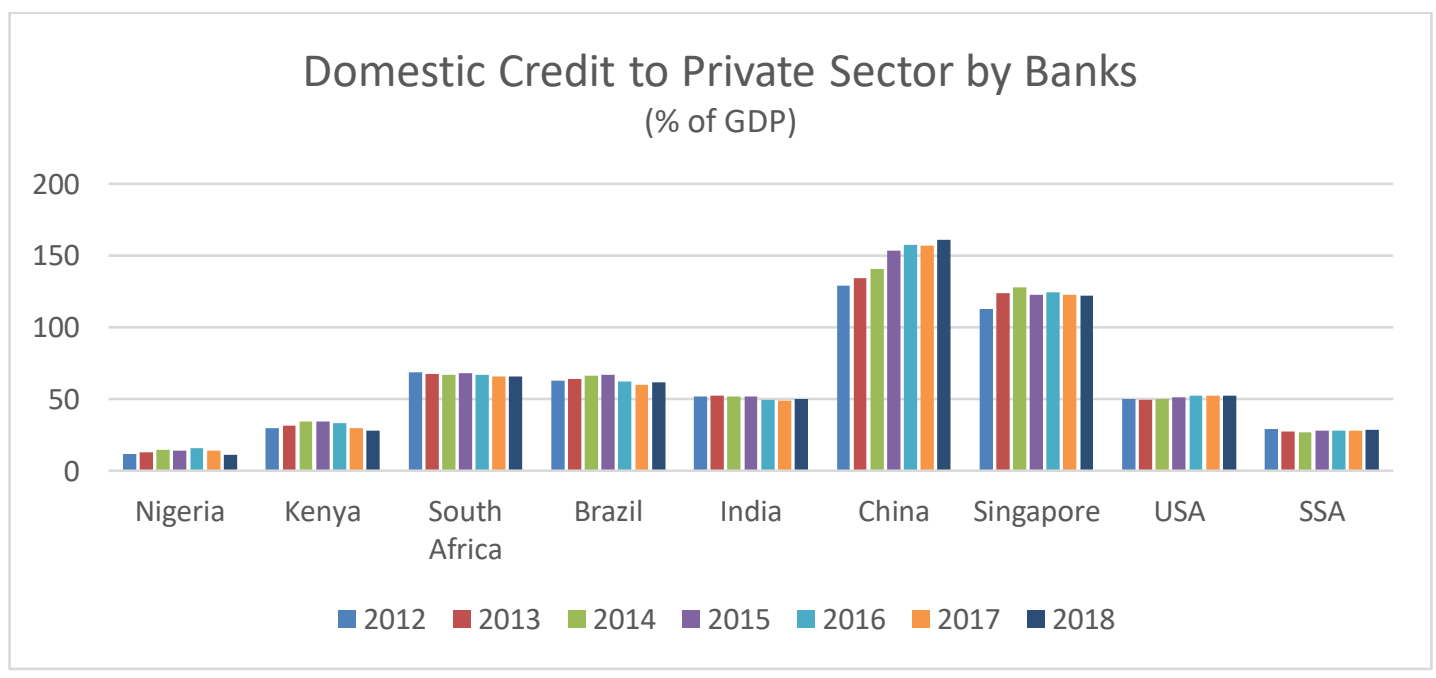

Data Sourced from https://data.worldbank.org/

A review of access to credit show the correlation between financial services sector development and the earlier reviewed charts on ICT infrastructure. The countries, namely USA, Singapore, 
International Journal of Social Science and Economic Research

ISSN: $2455-8834$

Volume: 05, Issue: 06 "June 2020"

Brazil, and China with better access to fixed broadband and mobile cellular services also have higher domestic credit to private sector than Nigeria.

\subsection{THE NIGERIAN EXPERIENCE}

\section{ICT Investment and Banking Services}

The Banking sector in Nigeria is the most developed within the financial services sector. Notwithstanding, the level of development in the banking sector, access to banking services was largely constrained until the 1990s after the deregulation of banking services sector and the investment in telecommunications infrastructure in Nigeria as well as private investment by banks in computer technology.

The reforms in the telecommunication sector in Nigeria since the advent of democracy especially the introduction of mobile telephony in the early 2000s has facilitated the provision of banking service through internet banking, mobile money, card payments, electronic fund transfers and Automated Teller Machines (ATMs) (Imhonopi \& Urim, 2013). This was sequel to previous development in the mid-1990s such as the licensing of internet service providers by the Nigeria Communications Commission in 1996. The provision of internet backbone facilitated the use of Wide Area Network (WAN) and the core banking application to extend banking services and to make possible the window for accessing bank account or operating it in any branch location regardless of the branch where the account was opened. Requisite investment was however required in the 1990s to upgrade the telecommunication infrastructure and lay foundation for the application of ICT in various sectors of the economy and particularly the financial services sector, with the banking industry taking the lead.

The Nigeria Telecommunication (NITEL), the defunct government telecommunication company, was supported by the United Nations Development Programme (UNDP) with a US\$1 million to enable NITEL establish the internet backbone (Vanguard Newspaper Nigeria, 2010). The investment in internet backbone infrastructure was therefore the critical social overhead capital needed to spur the usage of ICT in the banking industry. Equally, the deployment of ICT, in the form of wide area network and networking of bank's branches, enhanced information and addressed information asymmetry in the case of borrowers that could access and default on multiples loans from various banks' branches without adequate information necessary for the purposes of risk management. Weak risk management arising from poor information on lenders was arguably responsible for impaired lending activities of banks due to high-levels of NonPerforming Loans (NPLs) which characterized the pre-1990s banking industry in Nigeria. In the 2000s, credit bureaux commenced operations and provided credit scoring services based on the data exchange among banks. This was made possible by ICT applications which leveraged the 
available telecommunication, computer software and in recent times big data analytics and processing of multidimensional data from various sources including internet, social media and usage of smartphone riding on the mobile telephony infrastructure for which Nigeria attracted investment in the 2000s following the privatization reforms in the telecommunications sector. It can be argued that without the investment in the internet backbone infrastructure, most of the progress made would have eluded the country.

Investment in information and communication technology (ICT), especially requisite enabling infrastructure therefore is deemed critical for the application of innovation in the financial services sector and the development of the sector. It has been established that digitisation of banking or the use of ICT applications in the banking industry enables banks to expand their customer base thereby improving access to financial services (Laxmikanthanayaka \& Laxmana, 2018). However, the digital divide caused by inadequate investment in cutting edge infrastructure such as broadband telecommunication and satellite communication has made internet service inaccessible to several and those with the service, make do with epileptic service as a result of poor infrastructure in the telecommunication sector.

The initial investment in the mobile telephony and the internet infrastructure as well as mobile phone and internet penetration in Nigeria resulted in the adoption of electronic payments and mobile payments. The progress made in Nigeria is reflected in the following graphic illustration:

\section{Figure 4: Value of Electronic Payments Transactions in Nigeria}

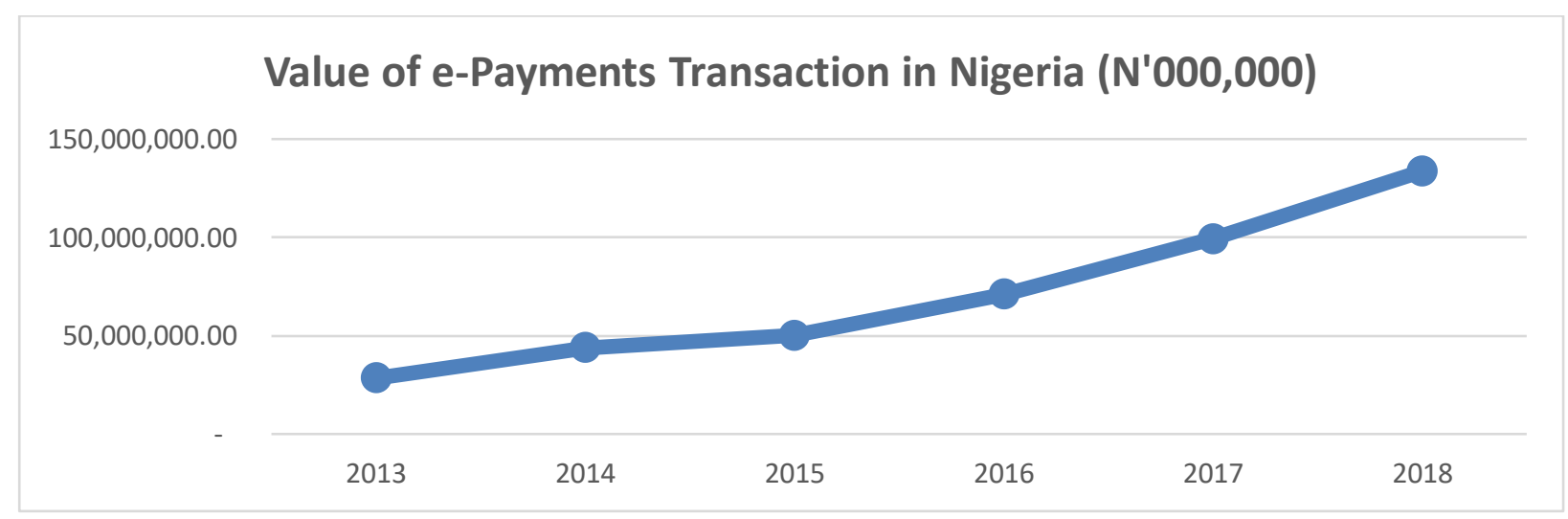


International Journal of Social Science and Economic Research

ISSN: $2455-8834$

Volume: 05, Issue: 06 "June 2020"

Figure 5: Volume of Electronic Payments Transactions in Nigeria

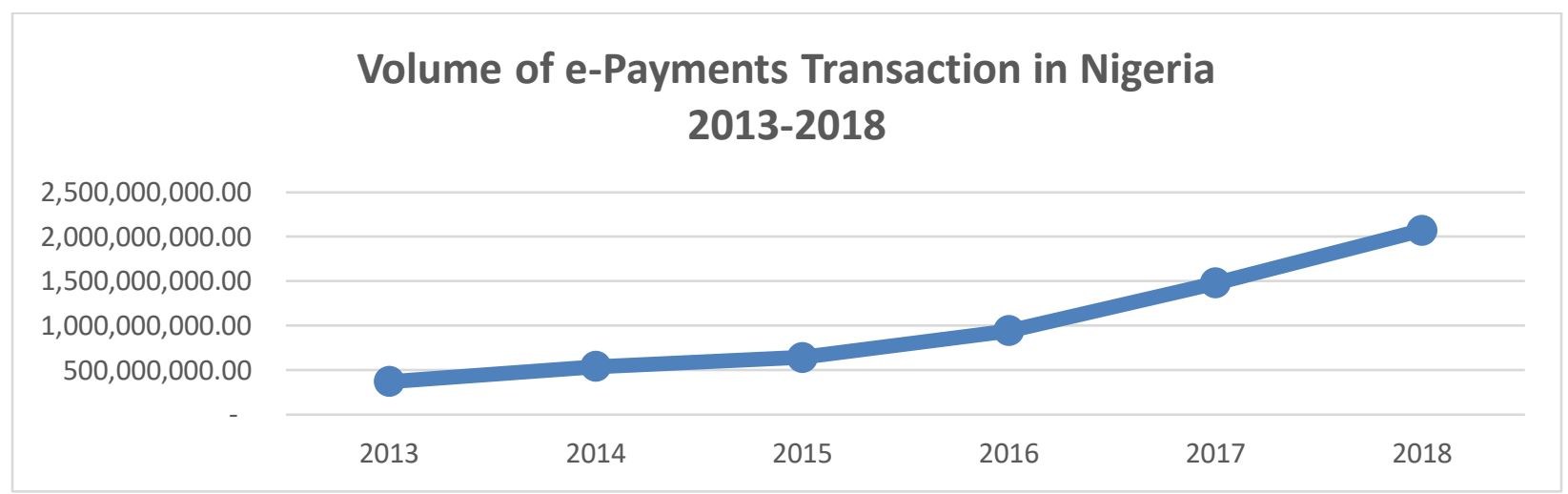

Data Source: Central Bank of Nigeria ( http://statistics.cbn.gov.ng/cbn-onlinestats/)

The compounded annual growth rate of electronic payments in Nigeria over the six-year period computed based on data from the Central Bank of Nigeria was 33.24 per cent.

\section{Challenges}

Notwithstanding the progress indicated in the charts above, the diffusion of the usage of modern banking technology is still limited as most of the transactions were largely transactions at the urban centres. We posit that the limitation is due to the inadequacy of ICT infrastructure in remote rural areas. A key example of investment gap in ICT in Nigeria is the limited fibre-optic cable coverage across Nigeria. Fibre-optic cable is required to extend broadband internet within Nigeria. For example, the CEO of Main One Company in Nigeria had asserted that the cost of moving internet traffic from Lagos to Abuja quadruples the cost of moving same traffic from London to Lagos. This is a key constraint as it has been indicated that most fibre-optic backbone terminates connection in capital cities across the states of the Nigerian Federation and extend at best to few urban locations. Most of the investment in fibre optic laying across Nigerians are private investors and the last mile fibre optic connection is grossly inadequate because most terminations are at multinational organisations, Base Transmission stations (BTS), big enterprise networks and a few universities. Connections to household are therefore limited. It is also important to note that between the two internet access infrastructure (i.e. wireless and wired), the wireless connection through GSM technology is predominant in Nigeria, whereas the wired (fibre optic) which should deliver better services is sparsely available. Key challenges to the rapid deployment of fibre optic in Nigeria includes; costly and cumbersome right of way approvals for private investors, poor town planning, lack of shared services among providers, security challenges and low government involvement (Agboje, Adedoyin, \& Ndujiuba, 2017). While most banks have point to point fibre-optic connection from their headquarters to their 
branches to enable enhanced connections most users of banking services do not have such access to enable them take advantage of more efficient services through their banks' electronic products and services.

In a similar vein, most Nigerian households in the rural areas do not have access to computer and internet as indicated by (Oluwatayo \& Ayodeji, 2017):

Table 1: Ranking of ICT Accessed by Nigerians

\begin{tabular}{cclcc}
\hline ICT Type & $\begin{array}{c}\text { Urban } \\
\text { Percentage }\end{array}$ & Rank & $\begin{array}{c}\text { Rural } \\
\text { Percentage }\end{array}$ & $\begin{array}{c}\text { Ran } \\
\mathbf{k}\end{array}$ \\
Radio & 92.55 & $2^{\text {nd }}$ & 86.09 & $1^{\text {st }}$ \\
Television & 83.82 & $3^{\text {rd }}$ & 42.08 & $3^{\text {rd }}$ \\
\hline Mobile Phone & 96.03 & $1^{\text {st }}$ & 82.03 & $2^{\text {nd }}$ \\
Personal Computer & 14.34 & $4^{\text {th }}$ & 4.84 & $4^{\text {th }}$ \\
\hline Internet & 12.42 & $5^{\text {th }}$ & 2.55 & $5^{\text {th }}$ \\
\hline
\end{tabular}

Source: Survey by (Oluwatayo \& Ayodeji, 2017)

In view of the above, they cannot have access to financial services accessible through this technology although a good number has access to mobile telephony which explains the growing popularity of financial services through unstructured supplementary service data (USSD) in Nigeria. USSD is a basic value-added service that could be accessed through the mobile phone without internet access.

The level of access to computers and the internet is indicative of the limitation of the investment in ICT as many people cannot access financial services through this means. Deepening the financial services sector in Nigeria therefore requires further investment in ICT to make it accessible at affordable prices for more Nigerians to have access to financial services.

\section{Policy Considerations for Nigeria}

Because of the apparent gap in ICT investment which is constraining the use of ICT to deepen the financial services sector, we reckon that there is need to improve investment in requisite ICT infrastructure for last-mile digital inclusion. It is our view that digital inclusion precedes financial inclusion. We advocate the following should be consideration for appropriate policy:

- Increase in government expenditure on ICT Infrastructure, especially in areas that may be considered not viable by the private sectors in the rural areas. ICT is a social capital that requires initial outlay by the government to invite further investment and innovation by the private sector; 


\section{International Journal of Social Science and Economic Research}

ISSN: $2455-8834$

Volume: 05, Issue: 06 "June 2020"

- Provide enabling policies to remove structural issues that increase the cost of investing in ICT infrastructure by the private sector. For example, improvement in the procedures for obtaining right of way approvals;

- Designate ICT Infrastructure as critical national infrastructure as provided in the Cybercrimes (Prohibition, Prevention, etc.) Act 2015 to ensure adequate security of ICT infrastructure across the country;

- Initiate policies that incentivise availing of credit to private investment in ICT infrastructure to enable the deepening of the financial services sector. The symbiotic relationship between the ICT sector and the financial services sector should be further explored;

- Remove duties and taxes that increase the cost of mobile telephony and internet services as well as electronic and mobile financial services to encourage usage.

The above policy issues require urgent attention as delaying would continue to prevent Nigerians from enjoying the opportunities available through the use of financial services that could be made available through ICT. Our experience so far indicated that the investment into ICT in the 2000s has encouraged the enterprise and innovation among financial technology providers who are enabling access to financial services. Furthermore, countries such as Singapore, USA, China and Brazil that have more significant investment in ICT and have encouraged financial technology companies have greater financial depth. It is instructive for Nigeria that their experience can be replicated if we prioritise investment in ICT.

\subsection{CONCLUSION AND RECOMMENDATIONS}

In view of the growth in electronic payments usage in Nigeria as earlier indicated and the fact that it was preceeded by increased investment in the telecommunication sector, we are convinced the ICT investment has a positive impact on financial sector deepening through its use effect. The use effect of ICT should interest Policymakers in the financial services sector because of its multidimensional impact through usage by both providers of financial services and users of financial services. The Central Bank of Nigeria had encouraged mobile money operators with its regulation on mobile money services which has gain acceptance among Nigerians thereby improving financial inclusion. Innovation leveraging ICT infrastructure such as the internet and its derivatives in the form of social media and big data has helped in the evolution of the financial services sector to leverage social information on the unserved segment of the society to address critical service constraints in the financial services sector such as credit reporting, credit provisioning, collateral management and cost of channels of service. For instance, in Nigeria, the national credit registry was made possible by ICT investment and users with movebale asset cannot have their assets registered to enable them access loans. 


\section{International Journal of Social Science and Economic Research}

ISSN: $2455-8834$

Volume: 05, Issue: 06 "June 2020"

The use effect of ICT through the financial services sector on economic growth and development is supported by studies using secondary panel data. However, we are positing that the use effect of ICT infrastructure on financial sector deepening may have been understated in view of the dearth of studies using primary data from the perspective of consumers of financial services. A study to evaluate from the perspective of the consumers on how digital inclusion through investment in ICT as a social overhead capital, has aided financial sector deepening is, therefore, a valuable proposition for further studies.

Notwithstanding, following our review of the theoretical underpinning and empirical assertions and statistics which supports the correlation between investment in ICT and financial sector deepening, we extend the following policy recommendations:

- The interlinkage of the ICT and the financial services sector should be explored to address the challenge of both digital and financial exclusion in Nigeria;

- There is a need for Nigeria to increase investment in ICT infrastructure to enable both traditional financial services providers and Fintechs to leverage it to extend reach of financial services to the unserved;

- ICT infrastructure investment in Nigeria should focus on harnessing the use effect of ICT to achieve financial deepening by investing in the enabling ICT infrastructure required for the extension of financial services. Such enabling infrastructure should support mobile telephony and internet services.

- Nigeria should attract further investment in ICT infrastructure that enables her to access virtual ICT infrastructure investment of other countries in the form of cloud computing, artificial intelligence etc. to address capital constraint and cost of financial services.

\section{REFERENCES}

Access Through Innovation Sub-Group of the G20 Financial Inclusion Experts Group. (2010). Innovative Financial Inclusion, Principles and Report on Innovative Financial Inclusion. IMaCS Research.

Adeusi, S. O., Dada, O., \& Adeosun, O. A. (2018). Effect of Financial Sector Deregulation on Economic Growth of Nigeria. International Journal of Academic Research in Business and Social Sciences Vol 8. No. 9, 1119-1132.

Agboola, A. A. (2001). Information and Communication Technology in Banking Operations in Nigeria- An Evaluation of Recent Experiences. Ife Journal of Economic and Finance Vol 5 No, $1 \& 2$. 
International Journal of Social Science and Economic Research

ISSN: 2455-8834

Volume: 05, Issue: 06 "June 2020"

Akinwunmi, O. A. (2018, June). Effect of Innovation and Policy on Financial Inclusion in Nigeria: 1981-2015. Academia.Edu.

Alliance for Financial Inclusion. (2016). Digital Financial Services Basic Terminology. Kuala Lumpur: Alliance for Financial Inclusion.

Andrianaivo, M., \& Kpodar, K. (2011, April). ICT, Financial Inclusion, and Growth: Evidence from African Countries. IMF Working Paper Vol 11 No. 73. International Monetary fund.

Arcand, J.-L., Berkes, E., \& Panizza, U. (2012). Too Much Finance? IMF Working Paper Vol 12.No 161. IMF Working Paper.

Banerjee, A. V., \& Duflo, E. (2004, March ). Growth Theory Through the Lens of Development Economics. Massachusetts, USA.

Bansal, S. (2014). Perspective of Technology in Achieving Financial Inclusion in Rural India. Procedia Economics and Finance Vol 11, 472-480.

Bashir, F., Rehman, H. u., \& Faridi, M. Z. (2013). Social Overahed Capital and Economic Output in Pakistan: An ARDL Bound Testing Approach. FWU Journal of Social Sciences Vol 7, No. 2, 181-192.

Central Bank of Nigeria. (2012). National Financial Inclusion Strategy. Abuja: Central Bank of Nigeria.

Chenery, H. B. (1952). Overcapacity and the Acceleration Principle Vol 20, No. 1. Econometrica, 1-28.

Duncombe, R., \& Boateng, R. (2009). Mobile Phone and Financial Services in Developing Countries: A Review of Concepts, Methods, Issues, Evidence and Future Research Directions. Third World Quarterly Vol 30, No.7, 1237-1258.

Garbard, K. D., \& Silber, W. L. (1978). Technology, Communication and the Performance of the Financial Markets: 1840 and 1975. The Journal of Finance, Vol 33, No. 3: Papers and Proceedings of the Thirty-Sixth Annual Meetings of American Finance Association of , (pp. 819-832). New York.

Giray, G. (2018). Determinants of the Domestic Credits in Developing Economies: The Role of Political Risks. Research in International Business and Finance 46, 430-443.

Goodwin, R. M. (1951). The Nonlinear Accelerator and the Persistence of Business Cycles . Econometrica Vol. 19 No. 1, 1-17. 


\section{International Journal of Social Science and Economic Research}

ISSN: $2455-8834$

Volume: 05, Issue: 06 "June 2020"

Hajli, M. N., Sims, J., \& Ibragimov, V. (2015). Information Technology (IT) Productivity Paradox in the 21st Century. International Journal of Productivity and Performance Management, 457-478.

Ibrahim, M., Ibrahim, O. A., \& Yakubu, A. S. (2019). Networking for Foreign Direct Investment in Africa: How Important are ICT Environment and Financial Sector Development? Journal of Economic Integration Vol 34. No. 2, 346-369.

Ikegami, J. (1966). Social Overhead Capital and Public Finance. The Kyoto University Economic Review Vol 36. No. 80.

Imhonopi, D., \& Urim, U. M. (2013). ICTs and the Digitisation of the Banking Industry in Nigeria. In D. o. Sociology, A Panoply of Readings in Social Sciences: Lessons for and from Nigeria (pp. 307-324). Ota, Ogun: Covenant University .

Jagtiani, J., \& Lemieux, C. (2018). Do Fintech Lenders Penetrate Areas that are Underserved by Traditional Banks? Journal of Economics and Business Vol 100, 43-54.

Janke, F., Packova, M., \& Pridavok , M. (2015). Stock Market Reaction to ICT Implementation: Model Based on Comparison of Developed and Transition Economies. E+M Finance Vol 18. No. 3, 91-100.

Karimo, T. M., \& Ogbonna, O. E. (2017). Financial Deepening and Economic Growth Nexus in Nigeria: Supply-LEading or Demand-Following? Economies MDPI.

Koyck, L. M. (1955). Distributed Lags and Investment Analysis. Louvain Economic Review Vol 21 No.1, 123.

KPMG, Nigeria; (2016). Fintech in Nigeria: Understanding the Value Proposition. Lagos: KPMG Nigeria.

Kumar, R. R., \& Vu, H. T. (2014). Exploring the Nexus Between ICT, Remmittances and Economic Growth- A study of Vietnam. Journal of South East Asian Economics Vol 31, No. 1, 104-120.

Laudon, D. P., \& Laudon, J. P. (2001). Management Information Systems: Organisation and Technology in the Network Enterprises. Prentice Hall International.

Laxmikanthanayaka, T. O., \& Laxmana, P. (2018). Digitalisation in the Banking Sector. International Journal of Trend in Scientific Research and Development . 
International Journal of Social Science and Economic Research

ISSN: 2455-8834

Volume: 05, Issue: 06 "June 2020"

Luca, O., \& Spatafora, N. (2012). Capital Inflows, Financial Development and Domestic Investment: Determinants and Inter-relationships. International Monetary Fund Working Paper No. 12/120.

Lynch, D. (1996). Measuring Financial Sector Development: A Study of Selected Asia-Pacific Countries. The Developing Economies Vol 34, No. 1.

Onyinyechi, U. G. (2019). Financial Deepening, Financial Intermediation and Nigerian Economic Growth: Time Variant Analysis. American International Journal of Business and Management Studies Vol 1. No. 1.

Oulton, N. (2010, November). Long-Term Implications of the ICT Revolution: Applying the Growth Theoryan and Growth Accounting. Centre fro Economic Performance Discussion Paper No. 1027.

Romer, P. M. (1986). Increasign Returns and Long-Run Growth. Journal of Political Economy Vol 94, No, 5, 1002-1037.

Sahay, R., Cihak, M., N'Diaye, P., Barajas, A., Bi, R., Ayala, D., . . Yousefi, S. R. (2015). Rethinking Financial Deepening: Stability and Growth in Emerging Markets. IMF Staff Discussion Notes Vol 15, No.8.

Samargandi, N., \& Kutan, A. M. (2016). Private Credit Spillovers and Economic Growth: Evidence from BRICS Countries. Journal of International Financial Markets, Institutions and Money Vol 44, 56-84.

Seo, H. J., Lee, Y. S., \& Oh, J. H. (2009). Does ICT Investment Widen the Growth Gap? Telecommunications Policy Vol 33, No. 8, 422-431.

Solow, R. M. (1956). A Contribution to the Theory of Economic Growth. Quarterly Journal of Economics Vol 70, No.1, 65-94.

Todaro, M. P., \& Smith, S. C. (2015). Economic Development. Edinburgh: Pearson Education Limited.

Vanguard Newspaper Nigeria. (2010, October 27). Vanguard Newspapers. Retrieved from https://www.vanguardngr.com: https://www.vanguardngr.com/2010/10/internet-13-yearsof-growth-from-ground-zero-in-nigeria-from-1960-1996/amp/ 
International Journal of Social Science and Economic Research

ISSN: $2455-8834$

Volume: 05, Issue: 06 "June 2020"

Vu, K. M. (2011). ICT as a Source of Economic Growth in the Information Age:Emprirical Evidence from the 1996 - 2005 Period. Telecommunications Policy Vol 35, No. 4, 357372.

Waverman, L., Meschi, M., \& Fuss, M. (2005). The Impact of Telecoms on Economic Growth in Developing Countries. The Vodafone Policy Paper Series Vol 2, 10-23.

World Bank. (2019, October 24). World Bank Page on Financial Inclusion. Retrieved from World Bank Website: https://www.worldbank.org/en/topic/financialinclusion/overview 